DOI https://doi.org/10.30525/978-9934-588-90-7-82

\title{
ОСОБЛИВОСТІ ЗАСТОСУВАННЯ ТЕХНОЛОГІЇ «ПЕРЕВЕРНУТИЙ КЛАС» В УМОВАХ ДИСТАНЦІЙНОГО НАВЧАННЯ (НА ПРИКЛАДІ ВИКЛАДАННЯ ІНОЗЕМНОЇ МОВИ ДЛЯ СПЕЦІАЛЬНИХ ЦІЛЙ)
}

\author{
Заярна I. C. \\ кандидат педагогічних наук, \\ викладач кафедри іноземних мов \\ Інститут права
}

Київського національного університету імені Тараса Шевченка м. Київ, Украӥна

В умовах запровадженого дистанційного навчання в Україні, спричиненого пандемією коронавірусної хвороби COVID-19, викладачі іноземних мов шукають нові ефективні підходи та технології до навчання іншомовному спілкуванню, здатні забезпечити високу якість освітнього процесу у вищій школі. Одна 3 технологій, що набула особливої популярності в останні роки, є технологія «перевернутий клас».

3 огляду на вище зазначене вважаємо доцільним в межах цього дослідження розглянути особливості застосування цієї технології під час викладання іноземної мови в умовах дистанційного навчання, що i визначаємо метою цієї наукової роботи.

Сутність технології «перевернутий клас» (англ. flipped classroom) полягає у зміні послідовності етапів навчального процесу, коли вивчення нового матеріалу виноситься на самостійну роботу студентів, а його закріплення відбувається під час аудиторних занять. Принцип був запропонований у 2007 році американськими вчителями природничих наук Дж. Бергманом (J. Bergmann) та А. Самсом (A. Sams) й описаний ними у праці Flip your classroom: reach every student in every class every day [1].

Теоретичні та практичні аспекти реалізації технології «перевернутого класу» також досліджували провідні вітчизняні та зарубіжні науковці, зокрема, О. Барна, О. Кузьмінська, С. Попадюк, Т. Ярмольчук, R. Davies, B. Goodwin, S. Kong, B. Santikarn, J. Strayer та інші. Учені доходять спільної думки щодо ефективності технології «перевернутий клас», відзначаючи ії гнучкість та здатність до активного залучення студентів у навчальний процес, що, у свою чергу, дозволяє сформувати динамічне та творче середовище, у якому студенти навчаються критично мислити та 
спільно вирішувати поставленні завдання $[1 ; 2$, с. $365 ; 3$, с. 90]. Специфіку використання зазначеної технології під час навчання іноземної мови вивчали Л. Андрейко, А. Свсеєвої, Л. Конопляник, К. Мельникової, Л. Чоповської, P. Benson, J. Egbert, J. Hen, B. Holmberg та інших. Дослідники наголошують на ефективному впливі технології «перевернутий клас» на навчальний процес, спрямований на формування у студентів іншомовної компетентності [4, с. 39; 5, с. 133; 6, с. 209].

Разом $з$ тим, слід зазначити, що наукові розвідки вітчизняних $\mathrm{i}$ зарубіжних учених щодо впровадження технології «перевернутий клас» у навчальний процес стосуються змішаного навчання, тобто поєднання аудиторних занять і самостійної роботи студентів. В нових умовах дистанційного навчання зазначена технологія вимагає певної адаптації, а саме поєднання синхронного та асинхронного режимів роботи зі студентами. Новітні інформаційно-комунікаційні технології дозволяють цей принцип успішно реалізувати на практиці. Наш власний досвід викладання іноземної мови за фаховим спрямуванням студентамправникам дозволяє виокремити як ефективні для синхронного режиму роботи формати відеоконференцій та вебінарів. Для асинхронного навчання найбільш ефективними, на наше переконання, є системи управління навчанням (англ. Learning Management System).

3 метою реалізації основного принципу технології «перевернутий клас», під час асинхронного навчання доцільним буде виконання вправ та завдань на представлення нових граматичних структур та лексичних одиниць й автоматизацію дій з ними, а також на розвиток рецептивних умінь в аудіюванні та читанні. Обгрунтованим вважаємо також застосування асинхронного режиму для розвитку продуктивних умінь у письмі. Наведемо приклади інструкцій до вправ, які варто виконувати студентам самостійно в асинхронному режимі: Read the text and answer the questions; Listen to the discussion and decide whether the statements are true or false; Complete the gaps with the correct word; Put the words in the correct word form; Write a letter of advice to the client; Choose the correct option.

Синхронний режим роботи буде найбільш продуктивний для виконання комунікативних завдань, а також рецептивних та продуктивних типів вправ. Важливо, щоб синхронному режиму передував асинхронний. Це дозволить виявити прогалини у знаннях кожного студента та максимально їх усунути під час онлайн заняття. Ефективними будуть представлення презентацій на запропоновану тему, проведення дебатів та обговорення правових питань, висвітлених у текстах, які опрацьовувалися студентами самостійно, тощо. 
Підсумовуючи, зазначимо, що застосування технології «перевернутий клас» під час дистанційного навчання іноземної мови для спеціальних цілей має свої технічні, методичні та психологічні особливості, разом 3 тим є дієвим підходом до навчання студентів іншомовному спілкуванню. Технологія «перевернутий клас» вчить студентів самостійності у навчанні і дозволяе максимально ефективно використовувати ресурси під час занять, які проводяться у режимі реального часу.

\section{Література:}

1. Bergmann J., Sams A. Flip your classroom: Reach every student in every class every day. Washington, DC: Internal Society for Technology in Education, 2012, 112 p.

2. Davies R. S., Dean D. L., Ball N. Flipping the classroom and instructional technology integration in a college-level information systems spreadsheet course. Educational Technology Research and Development, 61(4), 2013. P. 563-580.

3. Барна О.В. Технологія змішаного навчання в курсі методики навчання інформатики. Відкрите освітнє е-середовище сучасного університету, № 2, 2016. С. 84-92.

4. Конопляник Л., Мельникова К. Використання технології «перевернутий клас» при навчанні фахової іноземної мови. Вісник Національного авіаційного університету. Серія: Педагогіка, Психологія, № 15,2019 . С. $38-45$.

5. Santikarn B., Wichadee S. Flipping the Classroom for English Language Learners: A Study of Learning Performance and Perceptions. International Journal of Emerging Technologies in Learning, Vol. 13, No. 9, 2018. P. 123-135.

6. Basal A. The Implementation of A Flipped Classroom in Foreign Language Teaching. Turkish Online Journal of Distance Education,Vol. 16 No. 4, 2015. P. 28-37. 